\title{
DEVELOPMENT OF A DEGREASING PROCESS FOR PAICHE SKINS (Arapaima gigas) FOR TANNING PRESERVING THE NATURAL PATTERN AND COLOR
}

\section{Abdón SEGUNDO ESPADA, Liliana MARRUFO SALDAÑA*, Julio BARRA HINOJOSA, Rosa CONTRERAS PANIZO}

Productive Innovation and Technological Transfer Center of Leather, Footwear and related industries (CITEccal Lima), Technological Institute of Production (ITP), Caquetá Ave. 1300, Rímac, 15094, Lima, Perú, asegundo@itp.gob.pe, Imarrufo@ itp.gob.pe, julio.barra.h@uni.pe, rcontreras@itp.gob.pe

Received: 28.11.2019

Accepted: 29.04 .2020

https://doi.org/10.24264/Ifj.20.2.3

DEVELOPMENT OF A DEGREASING PROCESS FOR PAICHE SKINS (Arapaima gigas) FOR TANNING PRESERVING THE NATURAL PATTERN AND COLOR

ABSTRACT. The utilization of Amazonian fish skins, like paiche, to obtain leather, has been gaining importance in Peru. The beauty of the pattern of this fish skin comes from its light beige color and the black strip that runs through its back. This research aimed to develop a degreasing process for the tanning of paiche skin, that allows to preserve its natural pattern and color in the finished leather. For this purpose, a mixture of degreasers, diesel oil, lipases, and surfactants was used. In tanned skins, physical-mechanical properties, such as tear strength, tensile strength, elongation percentage, and shrinkage temperature, were evaluated. The presence of fishy smell in tanned paiche skins was evaluated through an analysis of fat content, fatty acid profiles, and sensorial tests. Besides, wastewater of the process was characterized to determine $\mathrm{BOD}_{5}, \mathrm{COD}$, TSS, oils, and greases, TPH, phenols, and $\mathrm{pH}$. This wastewater was treated by a laboratory-scale system, based on sedimentation, sifting, and flocculation-coagulation. As a result, a degreasing process using $8 \%$ of diesel oil, $18 \%$ of surfactants and $1.2 \%$ of lipidic enzymes, applied in cycles before and after the pickling process, was established. This process allowed the conservation of pattern and color of skin and the reduction of polyunsaturated fatty acids that cause the fishy smell in the leather, which complied with physicalmechanical standards for making footwear, bags, and clothing. Thus, a reduction in the pollutant charge in wastewater was achieved to acceptable environmental levels.

KEY WORDS: paiche, Arapaima gigas, fishskin, tanning process, degreasing

\section{DEZVOLTAREA UNUI PROCES DE DEGRESARE PENTRU TĂBĂCIREA PIELII DE PEȘTE PAICHE (Arapaima gigas) PĂSTRÂND MODELUL ȘI} CULOAREA NATURALE ALE ACESTEIA

REZUMAT. Utilizarea pieilor de pești amazonieni, cum ar fi cea a peștelui paiche, pentru a obține piele finită, este o activitate care a căpătat importanță în ultimii ani în Perú. Frumusețea modelului pielii acestui pește este dată de culoarea sa bej deschis și de dunga neagră care îi străbate spatele. Această cercetare și-a propus să dezvolte un proces de degresare pentru tăbăcirea pielii de pește paiche, care să permită păstrarea modelului și a culorii naturale în pielea finisată. În acest scop, s-a utilizat un amestec de agenți de degresare, motorină, lipaze și agenți tensioactivi. S-au evaluat proprietățile fizico-mecanice ale pieilor tăbăcite, cum ar fi rezistența la sfâșiere, rezistența la rupere, procentul de alungire și temperatura de contracție. Prezența mirosului caracteristic al pieilor de pește paiche tăbăcite a fost evaluată prin analiza conținutului de grăsimi, a profilurilor acizilor grași și prin teste senzoriale. Pe de altă parte, apa uzată a fost caracterizată pentru a determina $\mathrm{CBO}_{5}, \mathrm{CCO}$, totalul materiilor solide în suspensie, uleiuri și grăsimi, totalul hidrocarburilor din petrol, fenoli și pH. Aceste ape uzate au fost tratate printr-un sistem de laborator, bazat pe sedimentare, cernere și floculare-coagulare. Drept urmare, s-a stabilit un proces de degresare folosind $8 \%$ hidrocarburi, $18 \%$ surfactanți și 1,2\% enzime lipidice, aplicate în cicluri înainte și după procesul de piclare. Acest proces a permis conservarea modelului și a culorii pielii și reducerea acizilor grași polinesaturați care provoacă mirosul caracteristic al pielii de pește, respectând standardele fizico-mecanice pentru confecționarea încălțămintei, genților și îmbrăcămintei. Astfel, s-a obținut reducerea poluanților din apele uzate la niveluri acceptabile.

CUVINTE CHEIE: paiche, Arapaima gigas, piele de pește, proces de tăbăcire, degresare

\section{DÉVELOPPEMENT D’UN PROCÉDÉ DE DÉGRAISSAGE DES PEAUX DE PAICHE (Arapaima gigas) POUR LE TANNAGE, EN PRÉSERVANT LE} MOTIF ET LA COULEUR NATURELS

RÉSUMÉ. L'utilisation de peaux de poisson amazoniennes, telles que la paiche, pour obtenir du cuir, est une activité qui a pris de l'importance ces dernières années au Pérou. La beauté du motif de peau de ce poisson est donnée par sa couleur beige clair et par la bande noire qui traverse son dos. Cette recherche vise à développer un procédé de dégraissage pour le tannage de la peau des poissons paiche, qui permet de conserver le motif et la couleur naturels du cuir fini. À cette fin, un mélange de dégraissants, d'hydrocarbures, de lipases et de tensioactifs a été utilisé. On a évalué les propriétés physico-mécaniques du cuir fini, telles que la résistance à la déchirure, la résistance à la traction, le pourcentage d'allongement et la température de retrait. La présence d'une odeur de poisson caractéristique dans les peaux de paiche tannées a été évaluée par une analyse de la teneur en matière grasse, des profils dracides gras et des tests sensoriels. Dıautre part, les eaux usées du procédé ont été caractérisées pour déterminer la $\mathrm{DBO}_{5}$, la DCO, le TSS, les huiles et les graisses, la TPH, les phénols et le pH. Ces eaux usées ont été traitées par un système de laboratoire basé sur la sédimentation, le tamisage et la floculation-coagulation. En conséquence, un processus de dégraissage utilisant $8 \%$ d'hydrocarbures, $18 \%$ de tensioactifs et $1,2 \%$ d'enzymes lipidiques, appliqué par cycles avant et après le processus de picklage, a été mis en place. Ce processus a permis de conserver le motif et la couleur de la peau et de réduire les acides gras polyinsaturés responsables de l'odeur caractéristique du cuir de poisson, conformément aux normes physico-mécaniques applicables à la fabrication de chaussures, de sacs et de vêtements. Ainsi, une réduction de la charge polluante dans les eaux usées a été atteinte à des niveaux environnementaux acceptables.

MOTS CLÉS : paiche, Arapaima gigas, peau de poisson, procédé de tannage, dégraissage

\footnotetext{
* Correspondence to: Liliana MARRUFO SALDAÑA and Julio BARRA HINOJOSA, Productive Innovation and Technological Transfer Center of Leather, Footwear and related industries (CITEccal Lima), Technological Institute of Production (ITP), Caquetá Ave. 1300, Rímac, 15094, Lima, Perú,Imarrufo@itp.gob.pe, julio.barra.h@uni.pe.
} 


\section{INTRODUCTION}

Paiche is an Amazonian fish species whose nutritional properties make it an important source of food $[1,2]$ with projections for the international market that has gained popularity in Peru. Its richness, however, lies not only in its meat but also in the waste generated from its use, from which, for example, scales with a high protein and mineral content can be obtained. The skin containing a peculiar pattern and color gives natural beauty and when tanned, items of clothing can be made with a high value.

The specialized report of PROMPERU stated that approximately 1227 tons of paiche were obtained from aquaculture and capture activities in 2015 [3], resulting in the production of around 400 tons of skin that could have a byproduct such as leather. It is true that significant efforts have been made in Peru to highlight the skin properties of this species as leather. There is a great deal of potential to exploit this commodity, which will make to add value to the aquaculture sector, resulting in major projects focused on the manufacturing of tanned fish skin that should be targeted to markets with high fashion standards, sophistication, and valuation of biodiversity.

Using paiche skins for tanning implies the development of a process adapted to the characteristics of this skin. The presence of high-fat content in the tanned skins can cause yellowing and the appearance of an unpleasant fishy smell. In contrast, preserving the natural color and pattern, comprising a light beige color and a black strip that crosses the back, means avoiding the use of materials that can either alter or deteriorate it, as happens in the case of conventional degreasing. The objective of this research was to develop a degreasing process based on diesel oil, enzymes, and surfactants that would allow a tanned skin with adequate physical, mechanical and sensory characteristics and particularly an imperceptible fishy smell to be obtained without deteriorating the natural color and pattern of the species. The development of this process also included the characterization of the effluents produced and treating them on a laboratory scale.

\section{EXPERIMENTAL}

\section{Materials and Methods}

The present research was developed in the tanning pilot plant of CITEccal Lima. The tanned paiche skins came from the aquaculture activity taking place in the region of Ucayali. To avoid microbiological degradation of the collagenic structure, it was recommended that once removed from the meat, they should be preserved immediately in a container containing brine at $20^{\circ}$ Baumé until the end of the fillet day. Afterward, they were scaled and treated with salt at $30 \% \mathrm{w} / \mathrm{w}$ on both sides, putting one skin above the other, allowing them to drain for 12 hours and freezing them until they are processed.

\section{Leather Processing}

Before starting the tanning process, the skins were conditioned by fleshing that allowed the removal of meat and fat adhered to the skin. Commercial chemicals were used in leather process: Wetting agent (UD-800), bactericide (Tensocide 85), probiotics (Prosoak ${ }^{\mathrm{TM}}$ ), degreasing surfactant (Cletapon FU-100), formaldehyde, lipid enzyme (Degreasing enzyme 7707), diesel oil (Diesel B5), emulsifier (Garapon $\mathrm{HE}$ ), salt, organic acid (Unictan TC-400), sodium bicarbonate, glutaraldehyde (GT-50), phenolic retanning agent (Floretan SF-Extra), fungicide (Tensocide EB), neutralizing agent (Trupotan NL), fatliquoring agent (Fospholicker 6146L), resin (Krotan DC), synthetic tanning agent (Blancotan W), filler (Filler FJ), mix of protein binder and wax (LA 5269), penetrating agent (PT Penetrante), urethane resin (PUR 3365) and mix of protein binder and polishing wax (LVH67).

The tanning process started with a twophase soaking, process that allowed the skins to return to their natural swelling state while removing dirt, soluble protein substances and preservatives [4-6]. In the pre-soaking phase, room temperature water, wetting agent, bactericide, formaldehyde, and degreasing surfactant were used. Following, in the main soaking, besides the products used in the presoaking, lipid enzymes were added, then, skins were washed and drained. 
To establish the optimal degreasing process, tests were carried out with mixtures of diesel oil, probiotics, degreasing surfactants, and lipid enzymes, according to the formulations listed in Table 1 (all weights were measured in w/w) [5-8].

Table 1: Degreasing processes evaluated in the tanning of paiche skins

\begin{tabular}{|c|c|c|c|c|c|}
\hline $\begin{array}{l}\text { Test } \\
\text { code }\end{array}$ & Process & Product & Amount (\%) & Temp. (으) & $\begin{array}{l}\text { Duration } \\
\text { (min) }\end{array}$ \\
\hline \multirow{4}{*}{$A$} & Degreasing & Diesel oil & 5 & 28 & 130 \\
\hline & \multirow{3}{*}{ Tanning } & Probiotics & 3 & & \\
\hline & & Glutaraldehyde & 2.25 & 28 & 440 \\
\hline & & Phenol-sulphonic syntan & 7.5 & & \\
\hline \multirow{5}{*}{ B } & \multirow[t]{3}{*}{ Degreasing } & Diesel oil & 5 & 28 & 100 \\
\hline & & Degreasing surfactant & 3 & & \\
\hline & & Lipid enzyme & 0.1 & & \\
\hline & \multirow[t]{2}{*}{ Tanning } & Glutaraldehyde & 3 & 28 & 360 \\
\hline & & Phenol-sulphonic syntan & 10 & & \\
\hline \multirow{10}{*}{ C } & \multirow[t]{4}{*}{ Degreasing } & Diesel oil & 4 & & 290 \\
\hline & & Degreasing surfactant & 15 & 28 & \\
\hline & & Lipid enzyme & 1 & & \\
\hline & & Emulsifier & 0.7 & & \\
\hline & Resting & 2 weeks & & & \\
\hline & \multirow{3}{*}{$\begin{array}{l}\text { Degreasing after } \\
\text { pickling }\end{array}$} & Degreasing surfactant & 4.5 & 28 & 275 \\
\hline & & Lipid enzyme & 0.2 & & \\
\hline & & Wetting surfactant & 0.2 & & \\
\hline & \multirow[t]{2}{*}{ Tanning } & Glutaraldehyde & 2.25 & 28 & 390 \\
\hline & & Phenol-sulphonic syntan & 7.5 & & \\
\hline \multirow{10}{*}{ D } & \multirow[t]{4}{*}{ Degreasing } & Diesel oil & 4 & & 290 \\
\hline & & Degreasing surfactant & 15 & 28 & \\
\hline & & Lipid enzyme & 1 & & \\
\hline & & Emulsifier & 0.7 & & \\
\hline & Resting & 1 week & & & \\
\hline & \multirow{3}{*}{$\begin{array}{l}\text { Degreasing after } \\
\text { pickling }\end{array}$} & Degreasing surfactant & 4.5 & 28 & 280 \\
\hline & & Lipid enzyme & 0.2 & & \\
\hline & & Wetting surfactant & 0.2 & & \\
\hline & \multirow[t]{2}{*}{ Tanning } & Glutaraldehyde & 2.25 & 28 & 390 \\
\hline & & Phenol-sulphonic syntan & 7.5 & & \\
\hline
\end{tabular}




\begin{tabular}{|c|c|c|c|c|c|}
\hline \multirow{12}{*}{ CP-6 } & Degreasing & Diesel oil & 6 & 28 & 380 \\
\hline & & Degreasing surfactant & 18 & & \\
\hline & & Lipid enzyme & 1.2 & & \\
\hline & & Emulsifier & 2.3 & & \\
\hline & & Humectant & 3 & & \\
\hline & Resting & 1 week & & & \\
\hline & & Degreasing surfactant & 6 & 28 & 295 \\
\hline & $\begin{array}{c}\text { Degreasing after } \\
\text { pickling }\end{array}$ & Lipid enzyme & 0.4 & & \\
\hline & & Emulsifier & 0.4 & & \\
\hline & & Humectant & 2 & & \\
\hline & Tanning & Glutaraldehyde & 2.5 & 28 & 390 \\
\hline & & Phenol-sulphonic syntan & 7.5 & & \\
\hline \multirow{12}{*}{$\mathrm{CP}-8$} & Degreasing & Diesel oil & 8 & 28 & 380 \\
\hline & & Degreasing surfactant & 18 & & \\
\hline & & Lipid enzyme & 1.2 & & \\
\hline & & Emulsifier & 2.3 & & \\
\hline & & Humectant & 3 & & \\
\hline & Resting & 1 week & & & \\
\hline & & Degreasing surfactant & 6 & 28 & 295 \\
\hline & Degreasing after & Lipid enzyme & 0.4 & & \\
\hline & & Emulsifier & 0.4 & & \\
\hline & & Humectant & 2 & & \\
\hline & Tanning & Glutaraldehyde & 2.5 & 28 & 390 \\
\hline & & Phenol-sulphonic syntan & 7.5 & & \\
\hline \multirow{11}{*}{$\mathrm{CP}-\mathrm{F}$} & Degreasing & Diesel oil & 8 & 28 & 380 \\
\hline & & Degreasing surfactant & 18 & & \\
\hline & & Lipid enzyme & 1.2 & & \\
\hline & & Emulsifier & 2.3 & & \\
\hline & & Humectant & 3 & & \\
\hline & Resting & 1 week & & & \\
\hline & & Degreasing surfactant & 3 & 28 & 115 \\
\hline & $\begin{array}{c}\text { Degreasing after } \\
\text { pickling }\end{array}$ & Lipid enzyme & 0.3 & & \\
\hline & & Emulsifier & 0.2 & & \\
\hline & Tanning & Glutaraldehyde & 2.5 & 28 & 390 \\
\hline & & Phenol-sulphonic syntan & 7.5 & & \\
\hline
\end{tabular}


The degreasing and tanning processes were the only ones to suffer modifications, that is why they need a more detailed explanation as presented in Table 1. The processes A, B, C and $D$ were developed first, to explore and adjust the characteristics of the degreasing of paiche skins, and processes CP-6, CP-8 and CP-F were carried out to improve the degreasing process.

In the case of the pickling process, it took place after degreasing in two phases, the first one consisted in adding a salt solution, and in the second, acidification by adding two parts of organic acid ( $1 \%$ per part), until the $\mathrm{pH}$ of the skins reached the value 3 .

A degreasing after pickling process was done, starting with the skin depickling with brine and basification with two parts of $0.5 \%$ sodium bicarbonate. Then degreasing was performed as presented in Table 1. Subsequently, the pickling process described above was repeated, leaving the skins prepared for tanning, a process where glutaraldehyde and phenol-sulphonic syntan compounds were applied as tanning agents. The shrinkage temperature of the tanned hides, determined by the NTP 291.036:2007 method, indicated a shrinkage of not over $5 \%$ at a temperature between 70 and $75^{\circ} \mathrm{C}$, maintaining a pH between 4 and 4.2 .

The skins thus obtained were washed and neutralized, then were fatliquored with a fatliquoring agent and a mixture of retanning agents. The leathers were smoothed, dried and softened before finishing, which consisted in adding a mixture of penetrating protein binders, waxes for polishing and urethane resin by spraying $[5,9]$.

\section{Evaluation of Fat Removal}

Fat removal in tanned leather was quantified by determining the fat content in raw and tanned leather using the method NTP201.016 2002 (Rev 2017) MEAT AND MEAT PRODUCTS. The fatty acids profile was characterized using the method ISO 12966. To determine the fishy smell, sensory tests were performed on tanned skins using a specified attribute grade test carried out by a panel of experts, specialized in the chemical analysis of leather samples from the CITEccal Lima Laboratory. Each expert was assigned nine test pieces per sample. Negative control was included in the specimens submitted for a test of tanned paiche skin with tannins without a fishy smell. The specimen showing the attribute to be tested was a tanned paiche skin with a highly perceptible fishy smell. The samples were randomly assigned to the analysts and their analysis was performed at least one month after their tanning process. It should be noted here that the analysts were blindfolded to avoid associating the color of the sample pieces with the degree of smell. The qualification criteria used in the sensory test were Imperceptible (1), Slightly perceptible (2), Moderately perceptible (3) and Highly perceptible (4).

For each expert, statistical analysis of the results was conducted using ANOVA analysis and multiple comparison tests (Tukey HSD/ Kramer Test and Dunnett Test) at a confidence level of $95 \%$, to establish significant differences of process samples $(A, B, C$, and $D)$ with negative control and between samples. Statistical analysis was performed with the use of Real Statistics in MS Excel.

\section{Evaluation of the Physical-Mechanical Quality of} Tanned Leather

The tanned samples were tested in the laboratory of CITEccal Lima to determine their physical-mechanical properties. The tests performed are tear resistance (NTP ISO 33772:2008. LEATHER: Physical and mechanical tests. Determination of resistance to tearing. Part 2: Double tear), tensile strength and percentage elongation (NTP ISO 3376:2012. LEATHER: Physical and mechanical tests. Determination of tensile strength and elongation percentage) and shrinkage temperature with the method (NTP 291.036:2007. PELETERIA. Physical tests. Determination of shrinkage temperature).

\section{Effluent Characterization and Treatment}

The tanning system effluents are defined by the parameters established by Supreme Decree No. 003-2002-PRODUCE, analyzing the content of Total Suspended Solids (TSS) (SMEWW-APHAAWWA-WEF Part 2540-D; 23rd Ed: 2017. Total Suspended Solids dried at $\left.103-105^{\circ} \mathrm{C}\right)$, oils and fat content (ASTM D3921 - 96 (Reapproved 2011). Standard Test Method for oil and Grease and Petroleum Hydrocarbons in Water (Validated) 2014), Biochemical Oxygen Demand (BOD5) (SMEWW-APHA-AWWA-WEF Part 5210 B; 23rd 
Ed:2017). Biochemical Oxygen Demand (BOD): 5-day BOD test), Chemical Oxygen Demand (COD) (SMEWW-APHA-AWWA-WEF Part 5220 D; 23rd Ed:2017. Chemical Oxygen Demand, Closed Reflux. Colorimetric Method) and potential of hydrogen ( $\mathrm{pH})$ (SMEWW-APHA-AWWAWEF Part 4500-H+-B; 23rd Ed: 2017. pH Value: Electrometric Method.), likewise, the content of phenols was evaluated (EPA Method 420.2:1974 Phenolics-Colorimetric, Automated 4-AAP With Distillation//EPA Method 420.4 Rev. 01.1993 Determination of Total Recoverable Phenolics By Semi-Automated Colorimetry. Validity 2013) and Total Petroleum Hydrocarbons (TPH) (EPA Method 8015C Rev.3: 2007. Nanhologenated Organics by Gas Chromatography).

The global effluent of the process, constituted by the contribution of the subprocesses, was submitted to a treatment based on the principles of sedimentation, liquidsolid separation (sieving) and coagulationflocculation, at laboratory scale for the reduction of the contaminant load. The procedure was carried out as follows: first, the grease was separated from the effluent by means of a decantation pear, leaving it to rest for 30 minutes, and then the solids were filtered with a Tyler mesh $\mathrm{N}^{\circ} 200(74 \mu \mathrm{m})$. Once the sample was filtered, it was diluted to a ratio of 1:9 with tap water. Next, a $10 \%$ ferric sulfate solution was prepared as a coagulant and Arisfloc 606 at $0.1 \%$ as a flocculant. The operating conditions are as follows: stirring speed $=200 \mathrm{rpm}$, stirring time $=$ 5 minutes/flocculation: stirring speed $=40 \mathrm{rpm}$, and stirring time $=10$ minutes. Post-treatment sedimentation time was 10 minutes, after which samples were taken and preserved for analysis of TSS, oils and fats, BOD5, COD, pH, phenols, and $\mathrm{TPH}$. The effluent samples were analyzed in an accredited Laboratory under the requirements of ISO 17025.

\section{RESULTS AND DISCUSSIONS}

Table 2 presents the results obtained in the determination of fat and the percentage concentration of fatty acids. The data shows that paiche skins have high-fat content, approximately $45 \%$ which is higher than those of sheep with values $30 \%-40 \%$ [10]. Other species, for example, cattle (2-4\%) and goats (12-15\%) have relatively lower fat concentration [11].

Table 2: Results of characterization of fatty acid types in raw and tanned skin

\begin{tabular}{cccc}
\hline Types of fatty acids & $\begin{array}{c}\text { Types of fatty acids expressed as \% } \\
\text { skin } \\
\text { crude }\end{array}$ & $\begin{array}{c}\text { Tanned paiche leather } \\
\text { Sample D }\end{array}$ & $\begin{array}{c}\text { Tanned paiche leather } \\
\text { - Sample CP-6 }\end{array}$ \\
\hline Saturated fatty acids & 20.53 & 6.38 & - \\
Monounsaturated fatty acids & 11.63 & 3.30 & - \\
Polyunsaturated fatty acids & 7.65 & 0.54 & - \\
Fat percentage & 45.00 & 11.30 & 11.00 \\
\hline
\end{tabular}

The removal of fats for the tanning of conventional hides is done during pre-tanning operations, including unhairing using alkaline substances [4, 12]. In the case of fish skins, the use of sulphides and alkalis leads to the removal of scales and pigments from the skins $[13,14]$, for this reason, in the present research this procedure was removed, as the aim of this project is to preserve the natural color and pattern of paiche skin, so degreasing process was done after soaking.

The difficulty in the degreasing process is that most of the natural fat is available in the dermis and is contained within fat cells, whose walls consist of a protoplasmic envelope inverted in reticular tissue. Hence, degreasing involves the release of fat from cell confinement and for this, it is necessary to achieve the diffusion of degreasers in the skin that has a three-dimensional tissue of collagen fibers. The diffusion includes transport of degreasing chemicals into the skin, emulsification of fat and the removal of emulsified fat [15]. One of the most effective ways used for fat removal in the tanning industry is the degreasing process using organic solvents, emulsifiers and/or a 
mixture of them $[11,15]$. The organic solvents used are kerosene [15], petroleum, diesel oil, trichloroethylene, and perchloroethylene [16]. An alternative to these materials, developed in recent years, is the use of enzymes, that are used for soaking, liming, deliming, degreasing and bating [16]. Protease and lipase are the main enzymes commercialized, making possible to decrease the amount of organic solvents and emulsifiers in the effluents, contributing to the efficiency of the degreasing process.

It is important to point out that a process of yellowing occurs when fats are not removed sufficiently, it is produced because of the oxidation of polyunsaturated fatty acids, which have two or more double bonds that are easily oxidized and converted to hydroxyperoxides, this process is produced by heat, light and humidity, and is favoured by the action of bacterial degradation $[17,18]$, responsible of giving off the fishy smell $[19,20]$. The results of the tests $A$ and $B$ presented good characteristics in tanned leather, nevertheless, after some days of finished the process, yellowing and giving off of fishy smell was observed in the tanned leather obtained in these processes, which meant that fats had not been removed enough. Thus, it was discarded to continue researching on the application of probiotics, as the defects presented by the skins implied the use of a larger quantity of this product, which increased the cost of the scaling process.

So, processes C and D were developed considering the emanation and oxidation of fats observed after tanning, that is why in these processes was considered a resting time after pickling, thought to evaluate the emanation of fats, in order to remove them in a second degreasing. Test $C$ consider two weeks of resting time, and D, one week, because of the great emanation and oxidation of fat observed during resting time in process $C$, so results in process $D$ seemed to be better, as finished leather does not show a significantly yellowing or fishy smell, these results were proved with fat analysis and odour tests. As result, the percentage of fats in tanned leather from process $D$ decreased significantly compared to raw leather, establishing a fat content of $11.3 \%$. The recommended fat level for leather according to G. John (1997) is in the range of $4-10 \%$. Table 2 lists the percentage of polyunsaturated fatty acids as $7.65 \%$. The removal of fat using degreasing formula $D$ resulted in a tanned skin with a concentration of polyunsaturated fatty acids of $0.54 \%$.

The detail analyses of the sensory odour test are listed in Tables 3, 4 and 5 while Figures 1, 2 and 3 present the graphical representation of the data. It is observed that Judge 1 established significant differences between the negative control and the samples $A$ and $B$. Comparing samples from tests $A$ and $B$, both with mode 4 (highly perceptible) as calification, correspond to the tanned samples that presented high yellowing, the negative control, with calification 2 (slightly perceptible), is a sample without fishy smell coming from a vegetable tanning. Sample $C$ does not present significant differences with the negative control after almost three months have elapsed since its tanning. Sample D (assayed after one month of tanning) presents significant differences with respect to others, its valuation being 1 , imperceptible, establishing significant differences regarding the negative control and the C sample. Regarding Judge 2, statistical analysis indicates that there are significant differences between the $A, B$, and negative control samples. The statistical mode for each of them was 3, 4 and 1 , respectively. Sample $C$ with mode 2 and sample $D$ with mode 1 , do not present significant differences with respect to the negative control, however, sample $D$ and sample $C$ present significant differences between them. Statistical analysis for Judge 3 indicates that samples A, B, C, D present modes 4, 4, 3 and 1 respectively, which differ significantly from the negative control presented by mode 2 . Samples $A$ and $B$ are significantly different from sample $C$ and this is statistically different from sample $D$. 


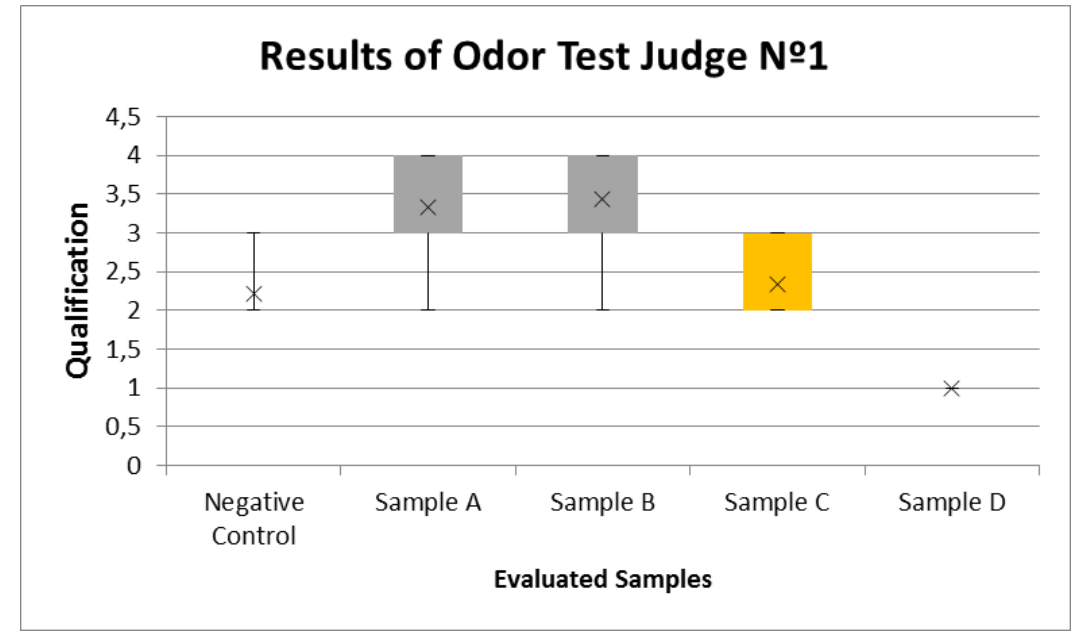

Figure 1. Results obtained by Judge 1 in the odour sensory test

Table 3: Analysis of the results obtained by Judge 1 Test Tukey HSD/Kramer

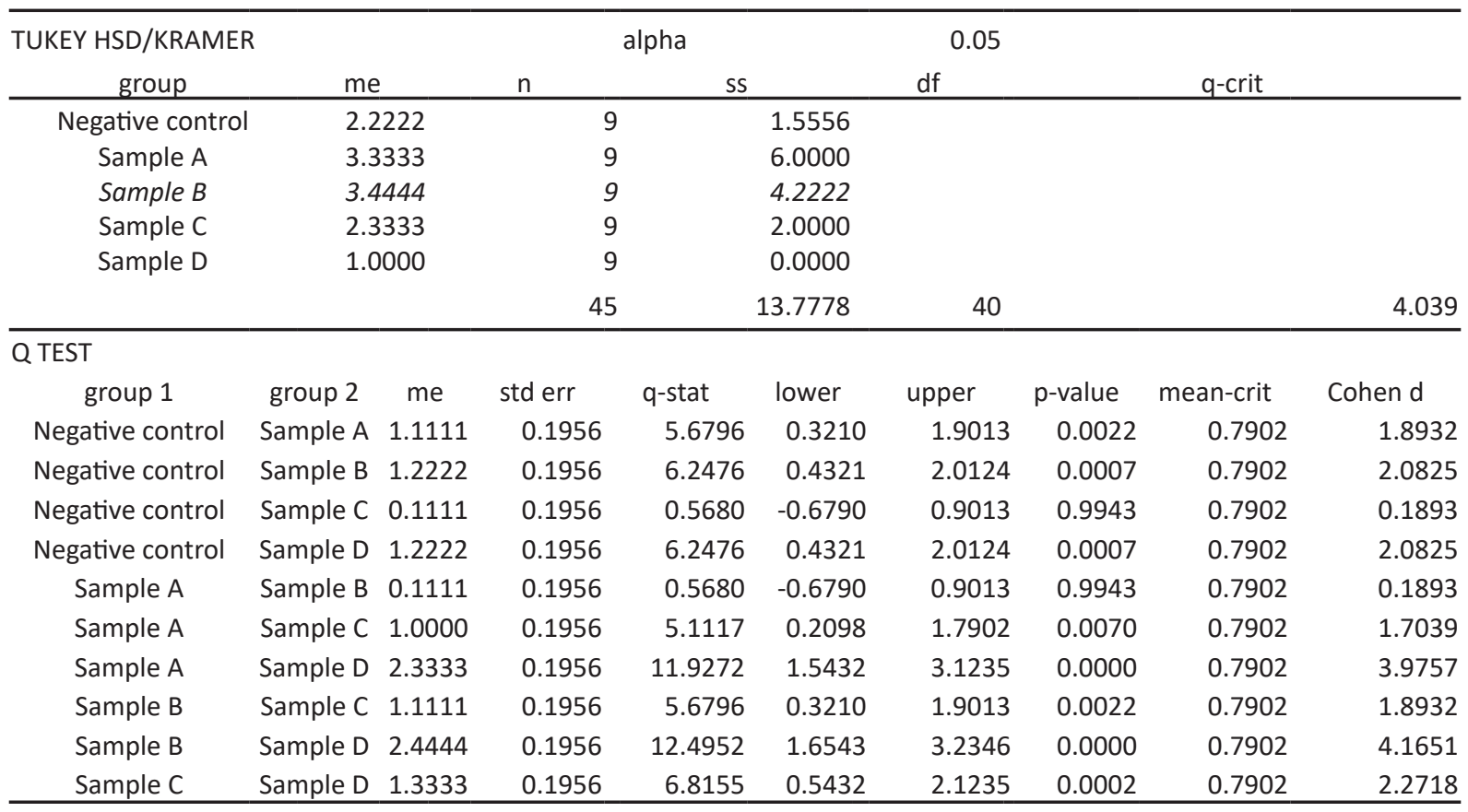

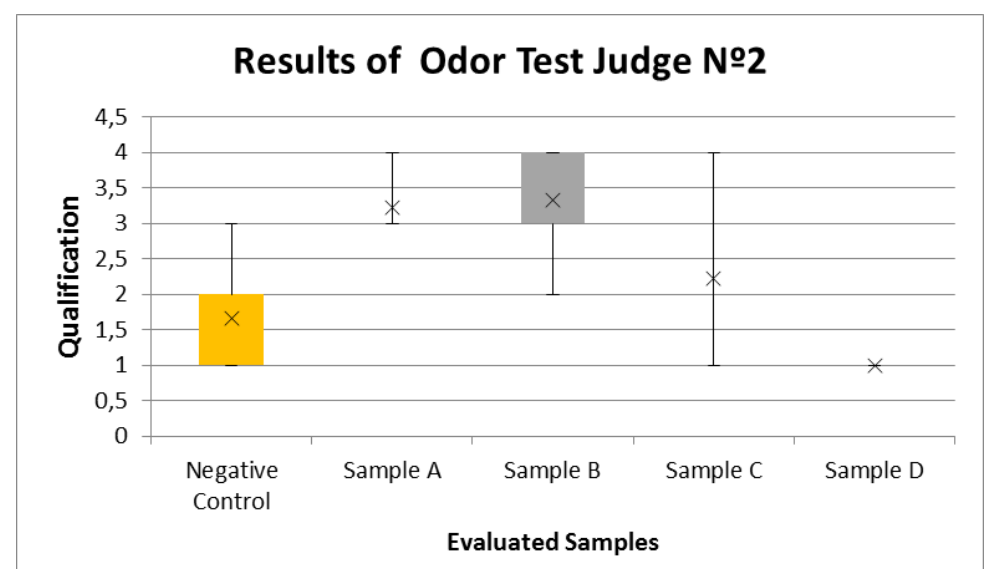

Figure 2. Results obtained by Judge 2 in the odour sensory test 
Table 4: Analysis of the results obtained by Judge №2 Test Tukey HSD/Kramer

\begin{tabular}{|c|c|c|c|c|c|c|c|c|c|}
\hline \multicolumn{3}{|c|}{ TUKEY HSD/KRAMER } & \multicolumn{3}{|c|}{ alpha } & \multicolumn{4}{|l|}{0.05} \\
\hline group & \multicolumn{2}{|l|}{ me } & $\mathrm{n}$ & ss & $\mathrm{df}$ & \multicolumn{4}{|c|}{ q-crit } \\
\hline Negative control & \multicolumn{2}{|c|}{1.6667} & 9 & \multicolumn{2}{|c|}{6.0000} & & & & \\
\hline Sample A & \multicolumn{2}{|c|}{3.2222} & 9 & \multicolumn{2}{|c|}{1.5556} & & & & \\
\hline Sample B & \multicolumn{2}{|c|}{3.3333} & \multirow{2}{*}{9} & \multicolumn{2}{|c|}{6.0000} & & & & \\
\hline Sample C & & 222 & & \multicolumn{2}{|c|}{5.5556} & & & & \\
\hline \multirow[t]{2}{*}{ Sample D } & \multicolumn{2}{|c|}{1.0000} & \multirow{2}{*}{$\begin{array}{r}9 \\
45\end{array}$} & \multicolumn{2}{|c|}{0.0000} & & & & \\
\hline & & & & \multicolumn{2}{|c|}{19.1111} & 40 & & & 4.039 \\
\hline \multicolumn{10}{|l|}{ Q TEST } \\
\hline group 1 & group 2 & me & std err & q-stat & lower & upper & $p$-value & mean-crit & Cohen d \\
\hline Negative control & Sample A & 1.5556 & 0.2304 & 6.7514 & 0.6250 & 2.4862 & 0.0002 & 0.9306 & 2.2505 \\
\hline Negative control & Sample B & 1.6667 & 0.2304 & 7.2336 & 0.7361 & 2.5973 & 0.0001 & 0.9306 & 2.4112 \\
\hline Negative control & Sample C & 0.5556 & 0.2304 & 2.4112 & -0.3750 & 1.4862 & 0.4425 & 0.9306 & 0.8037 \\
\hline Negative control & Sample D & 0.6667 & 0.2304 & 2.8935 & -0.2639 & 1.5973 & 0.2635 & 0.9306 & 0.9645 \\
\hline Sample A & Sample B & 0.1111 & 0.2304 & 0.4822 & -0.8195 & 1.0417 & 0.9970 & 0.9306 & 0.1607 \\
\hline Sample A & Sample C & 1.0000 & 0.2304 & 4.3402 & 0.0694 & 1.9306 & 0.0298 & 0.9306 & 1.4467 \\
\hline Sample A & Sample D & 2.2222 & 0.2304 & 9.6449 & 1.2916 & 3.1528 & 0.0000 & 0.9306 & 3.2150 \\
\hline Sample B & Sample C & 1.1111 & 0.2304 & 4.8224 & 0.1805 & 2.0417 & 0.0123 & 0.9306 & 1.6075 \\
\hline Sample B & Sample D & 2.3333 & 0.2304 & 10.1271 & 1.4027 & 3.2639 & 0.0000 & 0.9306 & 3.3757 \\
\hline Sample C & Sample D & 1.2222 & 0.2304 & 5.3047 & 0.2916 & 2.1528 & 0.0048 & 0.9306 & 1.7682 \\
\hline
\end{tabular}

\section{Results of Odor Test Judge №3}

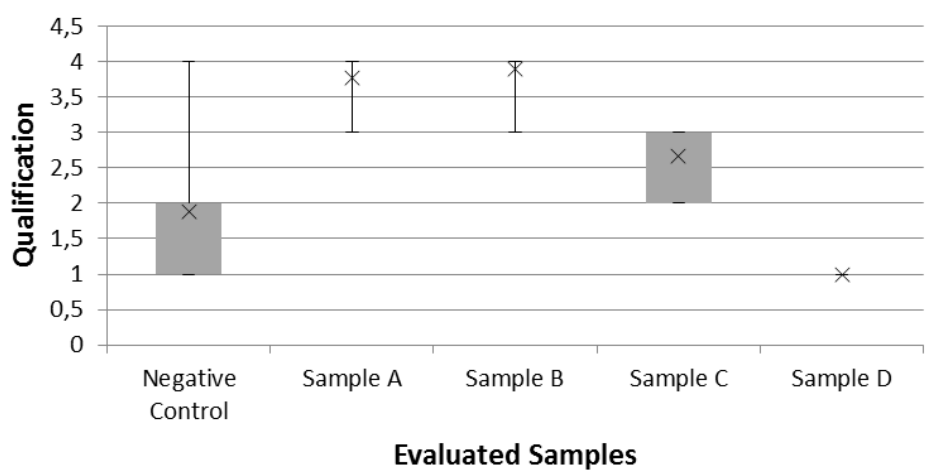

Figure 3. Results obtained by Judge 3 in the odour sensory test

Table 5: Analysis of the results obtained by Judge 3 Test Tukey HSD/Kramer

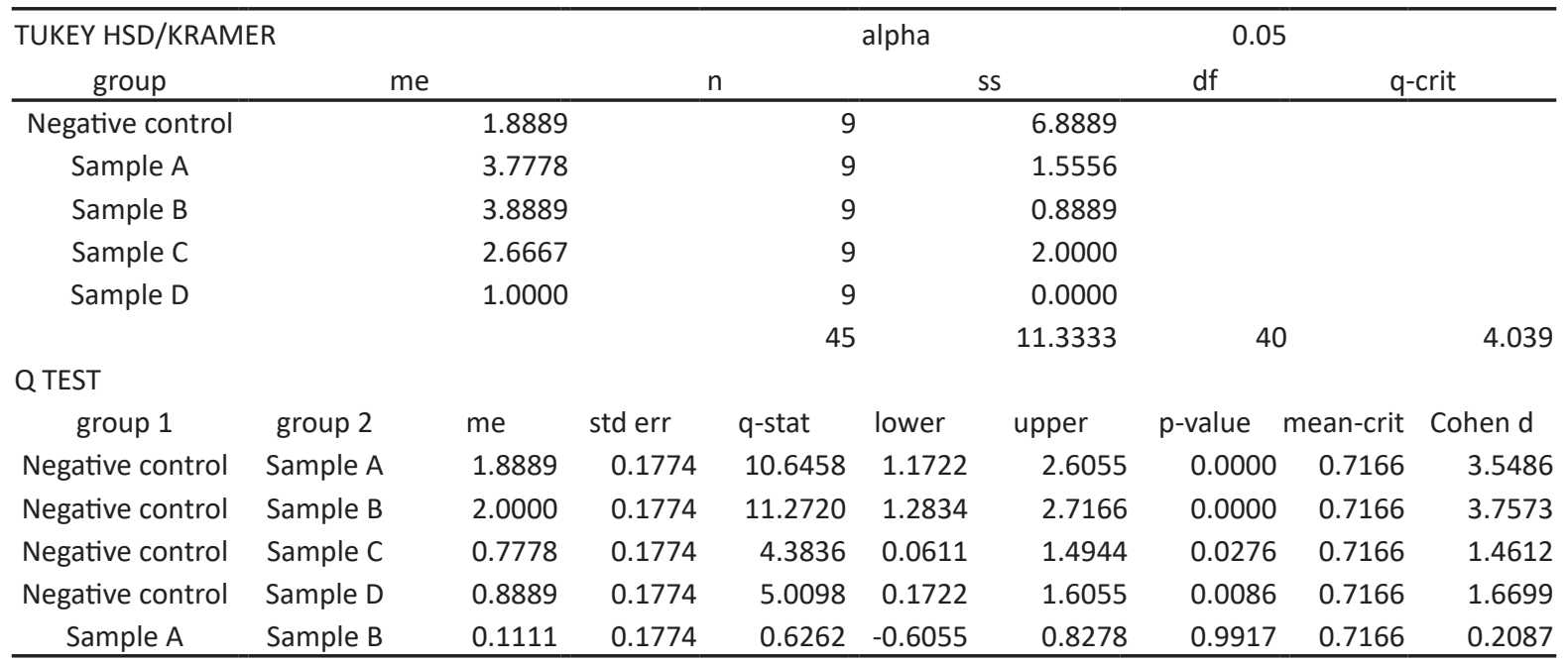




\begin{tabular}{llllrlllll}
\hline Sample A & Sample C & 1.1111 & 0.1774 & 6.2622 & 0.3945 & 1.8278 & 0.0007 & 0.7166 & 2.0874 \\
Sample A & Sample D & 2.7778 & 0.1774 & 15.6556 & 2.0611 & 3.4944 & 0.0000 & 0.7166 & 5.2185 \\
Sample B & Sample C & 1.2222 & 0.1774 & 6.8885 & 0.5056 & 1.9389 & 0.0002 & 0.7166 & 2.2962 \\
Sample B & Sample D & 2.8889 & 0.1774 & 16.2818 & 2.1722 & 3.6055 & 0.0000 & 0.7166 & 5.4273 \\
Sample C & Sample D & 1.6667 & 0.1774 & 9.3934 & 0.9500 & 2.3833 & 0.0000 & 0.7166 & 3.1311 \\
\hline
\end{tabular}

The "imperceptible" rating given by the three judges for the sample from process $D$ in the odour test would be supported by the decrease in the percentage of polyunsaturated fats and fatty acids achieved by the applied degreasing process. As observed in the sensory test, the three judges establish significant differences between samples $C$ and $D$, which would mean that oxidation of polyunsaturated fatty acids could have originated over time in process $\mathrm{C}$, making the difference in smell perceptible.
Thus, resting time was established in one week, and further processes were tested to evaluate the amount of degreasing products. Process CP- 6 and CP- 8 increase the amount of degreasing surfactant to $18 \%(\mathrm{w} / \mathrm{w})$, and diesel oil to $6 \%$ and $8 \%$ respectively (Table 2 ). The results obtained for fat content in CP-6 indicate that the removal is slightly higher than process D. In addition, the paiche leathers from CP-8 were lighter (absence of yellowing) compared with those obtained in previous processes, indicating a further removal of fat, so degreasing was established at $8 \%(\mathrm{w} / \mathrm{w})$.

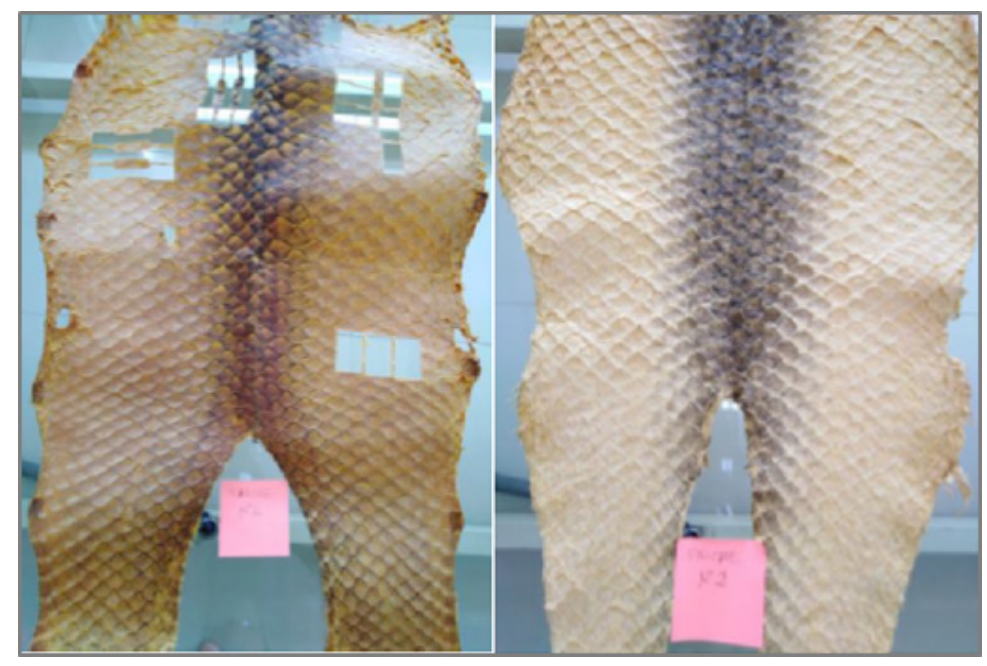

Figure 4. Samples of skins corresponding to tanning processes $A$ and $D$ respectively

The results of physical-mechanical properties presented in Table 6 show the evaluation of tear resistance, tensile strength and elongation percentage for tanned leather, values are within the standards as established by the technical norms and recommendations for manufacturing of footwear and articles of clothing and leather goods. The shrinkage temperature determined for skins tanned in this research with phenolic compounds syntan sulfonic and glutaraldehyde remains within the recommended minimum values for leather (>75\%) [21]. Tanning with alternative agents replacing chromium, in many cases, is not comparable to this metal because of the weak cross-linking capacity of these substitutes $[5,22]$. Researchers have reported earlier that the contraction temperatures for tanning with synthetic tanning agents such as polymerized phenols in the range of $75-85^{\circ} \mathrm{C}$ and glutaraldehyde in the range of $80-85^{\circ} \mathrm{C}$ [23]. The properties attained in tanned leather make it viable for use in the manufacture of footwear, clothing and leather goods. Figure 5 presents the prototypes elaborated with the tanned paiche skins obtained in the framework. 
Table 6: Physical-mechanical characteristics of tanned paiche skins

\begin{tabular}{|c|c|c|c|c|c|c|c|}
\hline \multirow[b]{2}{*}{ PARAMETER } & \multirow[b]{2}{*}{$\begin{array}{l}\text { Casual } \\
\text { Shoes }^{1}\end{array}$} & \multicolumn{3}{|c|}{ Application } & \multirow[b]{2}{*}{ Leather goods ${ }^{5}$} & \multirow{2}{*}{$\begin{array}{c}\text { Range of } \\
\text { values } \\
\text { obtained for } \\
\text { paiche leather }\end{array}$} & \multirow[b]{2}{*}{ Test Methods } \\
\hline & & Men Shoes ${ }^{2}$ & $\begin{array}{l}\text { Ladies } \\
\text { Shoes }^{3}\end{array}$ & Clothing ${ }^{4}$ & & & \\
\hline Tear Resistance & $\begin{array}{c}\text { Unlined: } \geq \\
100 \mathrm{~N} \\
\text { With lining: } \geq \\
70 \mathrm{~N}\end{array}$ & $\geq 40 \mathrm{~N}$ & $\geq 40 \mathrm{~N}$ & $\begin{array}{c}\text { Greater } \\
\text { than } 20 \\
\mathrm{~N}^{*}\end{array}$ & $\begin{array}{c}\text { Minimum } 400 \\
\mathrm{~N} / \mathrm{cm}\end{array}$ & $147 \mathrm{~N}-187 \mathrm{~N}$ & $\begin{array}{c}\text { NTP ISO } 3377- \\
02: 2008\end{array}$ \\
\hline Tensile strength & $\begin{array}{c}\geq 10.0 \mathrm{~N} / \\
\mathrm{mm} 2\end{array}$ & $\begin{array}{c}\geq 15.0 \mathrm{~N} / \\
\mathrm{mm}^{2} \text { in } \\
\text { splits }\end{array}$ & $\begin{array}{c}\geq 15.0 \\
\mathrm{~N} / \mathrm{mm}^{2} \\
\text { in splits }\end{array}$ & -- & Minimum 2250 & $\begin{array}{c}9.79 \mathrm{~N} / \\
\mathrm{mm}^{2} / 12.24 \mathrm{~N} / \\
\mathrm{mm}^{2}\end{array}$ & $\begin{array}{c}\text { NTP ISO } \\
3376: 2012\end{array}$ \\
\hline $\begin{array}{c}\text { Elongation at } \\
\text { break }\end{array}$ & $\begin{array}{l}\geq 15 \%(\rightarrow) \\
\geq 7 \%(\uparrow)\end{array}$ & -- & -- & -- & Maximum 50\%. & $76.40-94.47 \%$ & $\begin{array}{c}\text { NTP ISO } \\
3376: 2012\end{array}$ \\
\hline $\begin{array}{c}\text { Shrinkage } \\
\text { temperature }\end{array}$ & \multicolumn{5}{|c|}{ At least $70^{\circ} \mathrm{C}$ to $75^{\circ} \mathrm{C}$ with a shrinkage of no more than $5 \%$. } & $\begin{array}{c}\text { Above } 75^{\circ} \mathrm{C} \text { : } \\
\text { shrinkage } 4 \% \text {. }\end{array}$ & $\begin{array}{c}\text { NTP } \\
291.036: 2007\end{array}$ \\
\hline Odour & -- & -- & -- & -- & -- & $\begin{array}{l}\text { Imperceptible } \\
\text { to the fishy } \\
\text { smell }\end{array}$ & Sensory Testing \\
\hline
\end{tabular}

${ }^{1}$ NTP 241.023:2014. SHOES. Casual footwear. Railway applications - Requirements and test methods

${ }^{2}$ NTP 241.021:2015 FOOTWEAR. Men's footwear. Railway applications - Requirements and test methods

${ }^{3}$ NTP 241.022:2015 FOOTWEAR. Lady's footwear. Railway applications - Requirements and test methods

${ }^{4}$ NTP ISO 14931:2016. LEATHER: Guide for the selection of leather for clothing (excluding fur skins).

${ }^{5}$ Gerhard, J. (1996). Possible defects in leather production

*leathers with tear resistance greater than $10 \mathrm{~N}$ can be used as long as attention is paid to the design and construction of the garment.

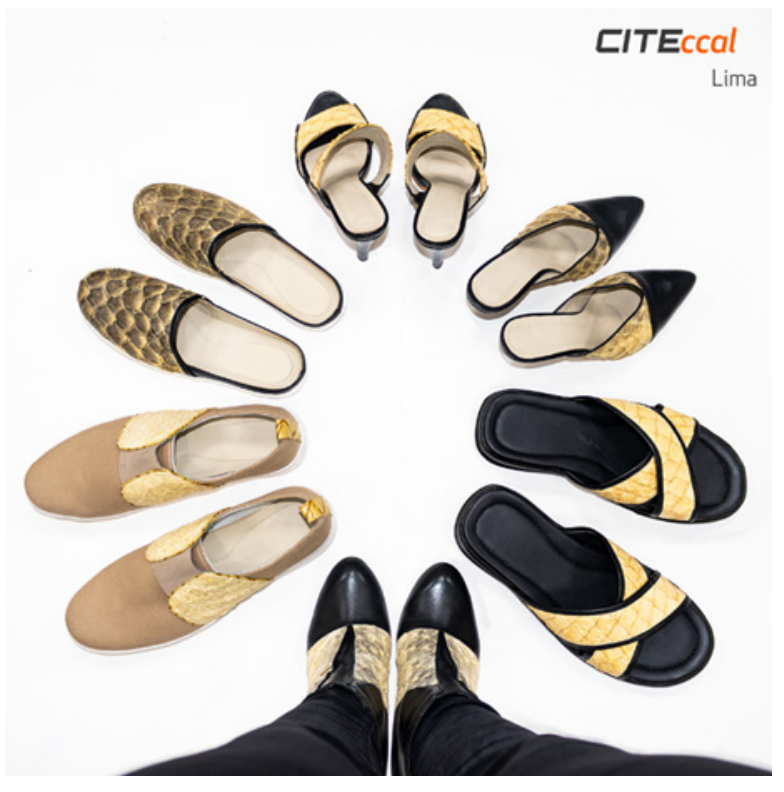

Figure 5. Items made with paiche skin preserving the pattern and color 
Finally, the effluents from tanning process were collected and characterized to determine its content of total suspended solids (TSS), $\mathrm{pH}$, oils and fats, biological oxygen demand (BOD5), chemical oxygen demand (COD), phenols, total petroleum hydrocarbons, which are presented in Table 7. Different samples were evaluated. First, in order to compare the effectiveness of degreasing after pickling process, effluents of degreasing from process CP-8 (sample DP-8) and effluents of degreasing from a process without second degreasing (DP-F) were characterized. From the results, it was determined that sample DP-8 is more efficient removing fats than $D P-F$, as its results of oils and fats are higher. Besides, effluents from whole process CP-8, and treated effluents from this process were characterized. The treatment was then carried out at laboratory scale, including sedimentation, filtration and coagulation-flocculation, achieving the removal of polluting charge at acceptable levels by national legislation for effluents from tanneries to be discharged to the sewage system, according to DS $\mathrm{N}^{\circ}$ 002-2003-PRODUCE for TSS, $\mathrm{pH}, \mathrm{BOD} 5$. The values of COD and oils and fats were exceeded by $18 \mathrm{mg} / \mathrm{L}$ and $116.3 \mathrm{mg} / \mathrm{L}$, respectively. Although the legislation for tanning liquid effluents does not include permissible values for phenols and hydrocarbons, the results obtained were compared with maximum admissible values established by the company that manages the potable water supply for Metropolitan Lima (SEDAPAL) and with permissible limits for refinery effluents regulated in $\mathrm{DS} \mathrm{N}^{\circ}$ 0.37-2008 -PCMO, respectively. With phenols, the values were not exceeded although the hydrocarbons exceeded the standard by 36.5 $\mathrm{mg} / \mathrm{L}$.

Table 7: Results obtained in degreasing effluents from the tanning process and in the treated effluent

\begin{tabular}{cccccc}
\hline Parameter & $\begin{array}{c}\text { Maximum } \\
\text { permissible limit - } \\
\text { sewer }\end{array}$ & DP-8 & CP-8 & DP-F ${ }^{4}$ & $\begin{array}{c}\text { Treated } \\
\text { effluent }^{5}\end{array}$ \\
\hline pH & $6.0-9.0$ & 5.30 & 4.19 & 5.70 & 6.11 \\
Total suspended solids (mg/l) & 500 & 2135.0 & 2500 & 2124 & 93 \\
Oils and fats (mg/L) & 50 & 11167.7 & 8318.2 & 9796.6 & 166.3 \\
BOD5 (mg/L) & 500 & 11270 & 9120 & 11500 & 358 \\
COD (mg/L) & 1500 & 33617 & 27366 & 25004 & 1519 \\
$\begin{array}{c}\text { Phenols *(mg/L) } \\
\text { Total petroleum } \\
\text { hydrocarbons }\end{array}$ & 0.5 & -- & 5.02 & -- & 0.21 \\
$* *$ (C10-C40) (mg/L) & 20 & 2622.1 & 2698.8 & 1571.2 & 56.5 \\
\hline
\end{tabular}

\footnotetext{
${ }^{1}$ Supreme Decree № 003-2002-PRODUCE - Peru

${ }^{2}$ Sample of effluent of degreasing from process $\mathrm{CP}-8$.

${ }^{3}$ Sample of effluent from whole process $\mathrm{CP}-8$.

${ }^{4}$ Sample of effluent of degreasing from process CP-F.

${ }^{5}$ Sample of treated effluent from whole process $\mathrm{CP}-\mathrm{F}$.

* Maximum admissible values SEDAPAL

** Maximum permissible limit for refinery effluents D.S. $\mathrm{N}^{\circ}$ 037-2008-PCMO
}

\section{CONCLUSIONS}

The degreasing of paiche skins for tanning, preserving color and pattern, is a process that must be controlled in such a way to avoid the yellowing of the tanned skins and the giving off of fishy smell. In this research, optimal fat removal was achieved through the use of a mixture of $8 \%$ diesel oil, $18 \%$ degreasing surfactants, and $1.2 \%$ lipid enzymes in repetitive cycles before and after pickling. The level of fat in the tanned skins reached a concentration of $11 \%$, a value that ensures an imperceptible level of fishy odour. The shrinkage temperature of the tanned leather and its physical-mechanical properties were within the standards established and recommended for use in the manufacture of footwear, clothing and leather goods. Based on the results obtained, it is recommended to study more about another degreasing processes using enzymes and biodegradable products, in order 
to improve the removal of fat and avoid the utilization of diesel oil in the degreasing process.

The effluents from the tanning process present high levels of organic pollutants, which, although were reduced on a laboratory scale through sedimentation, sieving, and coagulation-flocculation processes could not reach the permissible limits in all the parameters of the standard for discharge of effluents to the sewage system, so the removal process must be complemented with other methods to improve it, above all, the high content of oils and fats that characterizes this process, even more so, if it is projected to be implemented in regions where the discharge of liquid effluents is made directly in water surfaces that involve much lower permissible limits. The tanning of Amazonian fish skins is an activity that should be considered as an important opportunity to value these resources; however, the skins should come from formal aquaculture activity to avoid depredating them. Also, the tanning must be scaled up including the treatment of effluents to avoid negative impacts on the environment.

\section{Acknowledgements}

We acknowledge the National Innovation Program for Competitiveness and Productivity (Innóvate Perú) of the Ministry of Production of Peru for funding this research.

\section{REFERENCES}

1. Alcántara Bocanegra, F., Wust, W.H., Tello Martín, S., Rebaza Alfaro, M., Del Castillo Torres, D., Paiche el gigante del Amazonas, WUST Ediciones, 2006, $70 \mathrm{p}$.

2. Chu Koo, F., Fernández Méndez, C., Rebaza Alfaro, C., Darias, M.J., García Dávila, C.R., García Vásquez, A. et al., El cultivo del paiche: biología, procesos productivos, tecnologías y estadísticas, Repositorio Institucional IIAP, 2017, 110 p, available from: http:// repositorio.iiap.gob.pe/handle/IIAP/267.

3. PROMPERÚ. Informe Especializado Oportunidades Comerciales para el Paiche en Europa, Lima, 2017.

4. China Leather and Footwear Industry Research Institute, Developing countries training course on eco-leather manufacture technology.
5. Krishnamoorthy, G., Sadulla, S., Sehgal, P.K., Mandal, A.B., Green chemistry approaches to leather tanning process for making chromefree leather by unnatural amino acids, J Hazard Mater, 2012, 215-216, 173-82, https://doi. org/10.1016/j.jhazmat.2012.02.046.

6. Fotouh, D.M.A., Bayoumi, R.A., Hassan, M.A., Production of Thermoalkaliphilic Lipase from Geobacillus thermoleovorans DA2 and Application in Leather Industry, Enzyme Res, 2016, https://doi. org/10.1155/2016/9034364.

7. Singhania, R.R., Patel, A.K., Thomas, L., Goswami, M., Giri, B.S., Pandey, A., Industrial enzymes, Ind Biorefineries White Technol, 2015, 473-97, https://doi.org/10.1016/ B978-0-444-63453-5.00015-X.

8. Kılıç, E., Evaluation of degreasing process with plant derived biosurfactant for leather making: An ecological approach, Tekstil ve Konfeksiyon, 2013, 23, 2, 181-7.

9. Fischer, C., Izquierdo, F., Mähner, P., Drexler, J., Reetz, I., Segura, R., Fatliquoring from a viewpoint of sustainability, 31st IULTCS Congress, Valencia, España, 2011.

10. Afsar, A., Cetinkaya, F., Studies on the degreasing of skin by using enzyme in liming process, Indian J Chem Technol, 2008, 15, 5, 507-10.

11. Choudhary, R.B., Jana, A.K., Jha, M.K., Enzyme technology applications in leather processing, Indian J Chem Technol, 2004, 11, 5, 659-71.

12. Escoto-Palacios, M.J., Pérez-Limiñana, M.Á., Arán-Ais, F., From leather waste to functional leather, 2016, INESCOP, ISBN: 978-84-9342619-4, $60 \mathrm{p}$.

13. Hermiyati, I.H., Syabani, M.W.S., Silvianti, F.S. Vegetable Tanning Process of Starry Trigger Fish (Abalistes Stellaris) and its Plotting to Leather Products, 7th International Seminar on Tropical Animal Production (ISTAP), September 2017, 475-474.

14. Duraisamy, R., Shamena, S., Berekete, A.K., A Review of Bio-tanning Materials for Processing of Fish Skin into Leather, International Journal of Engineering Trends and Technology, 2016, 39, 1, 19.

15. Sivakumar, V., Chandrasekaran, F., Swaminathan, G., Rao, P.G., Towards cleaner degreasing method in industries: ultrasound-assisted aqueous degreasing 
process in leather making, J Clean Prod, 2009, 17, 1, 101-4, https://doi.org/10.1016/j. jclepro.2008.02.012.

16. Nawaz, H.R., Solangi, B.A., Nadeem, U., Zehra, B., Zeeshan, M., Preparation and Application of Degreasing Enzyme for Leather from Indigenous Resource: A Step for Reduction of Tannery Pollutants, 2011, Fourth International Conference Environmentally Sustainable Development, Pakistan.

17. Fujita, A., Isogai, A., Endo, M., Utsunomiya, H., Nakano, S., Iwata, H., Effects of sulfur dioxide on formation of fishy off-odor and undesirable taste in wine consumed with seafood, J Agric Food Chem, 2010, 58, 7, 4414-20, https:// doi.org/10.1021/jf9041547.

18. Sohn, J.-H., Taki, Y., Ushio, H., Kohata, T., Shioya, I., Ohshima, T., Lipid Oxidations in Ordinary and Dark Muscles of Fish: Influences on Rancid Off-odor Development and Color Darkening of Yellowtail Flesh During Ice Storage, J Food Sci, 2005, 70, 7, s490-6, https://doi.org/10.1111/j.1365-2621.2005. tb11497.x.

19. Afşar, A., Çetinkaya, F., A research on increasing the effectiveness of degreasing process by using enzymes, Tekstil ve Konfeksiyon, 2008, 18, 4, 278-83.

20. Sae-leaw, T., Benjakul, S., Fatty acid composition, lipid oxidation, and fishy odour development in seabass (Lates calcarifer) skin during iced storage, Eur J Lipid Sci Technol, 2014, 116, 7, 885-94, https://doi. org/10.1002/ejlt.201300381.
21. Kuria, A., Ombui, J., Onyuka, A., Sasia, A., Kipyegon, C., Kaimenyi, Ngugi, A., Quality Evaluation of Leathers Produced by Selected Vegetable Tanning Materials from Laikipia County, Kenya, IOSR J Agric Vet Sci Ver I, 2016, 9, 4, 13-17, https://doi.org/10.9790/23800904011317.

22. Valeika, V., Širvaityte, J., Beleška, K., Estimation of chrome-free tanning method suitability in conformity with physical and chemical properties of leather, Medziagotyra, 2010, 16, 4, 330-6.

23. Covington, A.D., Song, L., Suparno, O., Koon, H.E.C., Collins, M.J., Link-lock: An explanation of the chemical stabilisation of collagen, J Soc Leather Technol Chem, 2008, 92, 1, 1-7.

(C) 2020 by the author(s). Published by INCDTPICPI, Bucharest, RO. This is an open access article distributed under the terms and conditions of the Creative Commons Attribution license (http:// creativecommons.org/licenses/by/4.0/). 